\title{
Engineering integrative vectors based on phage site-specific recombination mechanism for Lactococcus lactis
}

\author{
Innanurdiani Koko ${ }^{1}$, Adelene Ai-Lian Song ${ }^{2,3^{*}}$ D, Mas Jaffri Masarudin ${ }^{1,3}$ and Raha Abdul Rahim ${ }^{1,3,4^{*}}$
}

\begin{abstract}
Background: Site-specific integration system allows foreign DNA to be integrated into the specific site of the host genome, enabling stable expression of heterologous protein. In this study, integrative vectors for secretion and surface display of proteins were constructed based on a lactococcal phage TP901-1 integrating system.

Results: The constructed integration system comprises of a lactococcal promoter $\left(P_{\text {nisA }}\right.$ or $\left.P_{170}\right)$, phage attachment site (attP) from bacteriophage TP901-1, a signal peptide (USP45 or SPK1) for translocation of the target protein, and a PrtP 344 anchor domain in the case of the integrative vectors for surface display. There were eight successfully constructed integrative vectors with each having a different combination of promoter and signal peptide; pS1, pS2, pS3 and pS4 for secretion, and pSD1, pSD2, pSD3 and pSD4 for surface display of desired protein. The integration of the vectors into the host genome was assisted by a helper vector harbouring the integrase gene. A nuclease gene was used as a reporter and was successfully integrated into the L. lactis genome and Nuc was secreted or displayed as expected. The signal peptide SPK1 was observed to be superior to USP45-LEISSTCDA fusion in the secretion of Nuc. As for the surface display integrative vector, all systems developed were comparable with the exception of the combination of $P_{170}$ promoter with USP45 signal peptide which gave very low signals in whole cell ELISA.
\end{abstract}

Conclusion: The engineered synthetic integrative vectors have the potential to be used for secretion or surface display of heterologous protein production in lactococcal expression system for research or industrial purposes, especially in live vaccine delivery.

Keywords: Lactococcus lactis, Integrative vector, Secretion, Surface display, Signal peptide

\section{Background}

Lactococcus lactis, a lactic acid bacteria (LAB) that has been conventionally known as a starter culture in food fermentations such as cheese and yoghurt, was granted with the Generally Recognized as Safe (GRAS) status by the US FDA. It is the most well studied LAB strain due to its well characterised genome which allows researchers to manipulate this bacterium for desired applications. L. lactis is also known as the model LAB and a

\footnotetext{
* Correspondence: adelene@upm.edu.my; raha@upm.edu.my

${ }^{2}$ Department of Microbiology, Faculty of Biotechnology and Biomolecular Sciences, University Putra Malaysia, 43400 UPM, Serdang, Selangor, Malaysia ${ }^{1}$ Department of Cell and Molecular Biology, Faculty of Biotechnology and Biomolecular Sciences, University Putra Malaysia, 43400 UPM, Serdang, Selangor, Malaysia

Full list of author information is available at the end of the article
}

promising bacteria in recombinant protein technology that has been extensively used as cell factory for the production of industrially important protein such as enzymes, compounds, antigens, allergens, and cytokines $[1-5]$.

Due to its extensive applications, numerous cloning and expression vectors have been constructed for this bacterium. However, the instability of the replicating plasmid DNA is a drawback where it can be lost under non-selective conditions [6]. Plasmid copy numbers often varies with growth, resulting in different expression levels of the genes they carry [7]. Besides, over expression of heterologous protein causes metabolic load which burdens the host and affect the protein integrity [8]. Due to these limitations, constructions of more stable expression systems were attempted through

(c) The Author(s). 2019 Open Access This article is distributed under the terms of the Creative Commons Attribution 4.0 International License (http://creativecommons.org/licenses/by/4.0/), which permits unrestricted use, distribution, and 
genomic integration of integrative vectors harbouring the desired gene in L. lactis. DNA integrating system has been demonstrated in other LAB such as Lactobacillus for vaccine construction, for instance, the expression of surface anchored llama heavy chain antibody against rotavirus [9-12] and other Gram-positive bacteria such as Bacillus sp. using spore surface display system to express target protein on the outer surface of bacteria [13]. The integrating system has also been long developed for surface display of target protein for vaccine production in mycobacteria $[14,15]$ and other applications [16-18]. The most well characterised, easy manipulated bacteria, Escherichia coli has a long lists of integrating systems developed to express various kinds of recombinant protein for numerous applications [19-24].

As reported by Leenhouts et al., (1990), chromosomal integration in L. lactis mediated by replacement recombination and Campbell-like mechanism [25] resulted in unstable integration and the integrated DNA fragment were gradually lost under non-selective condition. The instability of the integrated plasmid was due to its replicative activity and the direct repeats flanking the inserted DNA sequences resulted from the Campbelllike integration permitted intra-molecular homologous recombination by the host system. These conditions caused the integrated plasmid to be cleaved out from the genome, losing the integrated plasmid [26-28].

A site-specific recombination system for $L$. lactis has been developed to generate stable, single-copy chromosomal integration based on the lactococcal temperate bacteriophage TP901-1. The system requires phageencoded elements, which are the phage attachment site, attP and an integrase protein which facilitates recombination between the attP site and the bacterial attachment site, $a t t B$ on the host genomic DNA at a high frequency. For the recombination to occur, integrase recognises a short sequence of the site ( $43 \mathrm{bps}$ ) which makes the system applicable in numerous L. lactis strains [29-34]. Through utilisation of this established integration system, we developed a variety of integrative vectors for secretion and surface display of targeted proteins and compared their efficiency using nuclease as a reporter.

L. lactis possess only one exported housekeeping protease (HtrA), and secrete only one major extracellular protein, USP45, thus minimizing protein degradation by the extracellular proteolytic system, simplifying downstream purification [35]. Secretion is preferable in protein delivery when the target location is the digestive tract of humans or animals, because it facilitates interaction between the expressed protein and its target [36]. On the other hand, surface display enables expression of recombinant protein on the surface of bacteria for various applications such as live vaccine development, antibody production, peptide library screening, and production of whole-cell biocatalysis and bioadsorbents for environmental applications [37].

In this report, we describe the construction of a single-copy integration vector for $L$. lactis based on the TP901-1 site-specific recombination. The integrative vectors were suicide vectors for $L$. lactis host, designed to replicate in Escherichia coli for easy DNA manipulations. When it is transformed into the L. lactis, the vector integrates into the attB site of the genome and the expressed target protein is either secreted or surface displayed on the outer part of the cells. Different combinations of promoters and signal peptides were used and protein expression and secretion efficiency were compared between systems.

\section{Results}

Helper plasmid (pNZint)

L. lactis harbouring the helper plasmid, pNZint was analysed for the expression of integrase protein as integration of the foreign DNA is only possible with coexpression of the integrase gene. The integrase protein was tagged with 6 histidine residues to allow detection via Western blotting. Protein expression was analysed for $12 \mathrm{~h}$ post-induction $(20 \mathrm{ng} / \mathrm{ml}$ nisin) with $2 \mathrm{~h}$ intervals. The expected size of the desired protein was 55.6 $\mathrm{kDa}$ where expression of integrase was observed from 2 h onwards (Fig. 1).

\section{Vector constructions and integration}

A total of eight vectors, pS1-4 and pSD1-4 were successfully constructed as listed in Table 1 . The constructed secretion and surface display integrative vectors were subsequently cloned with $n u c$ gene, thereby named pS1-4nuc and pSD1-4nuc. The integrative vectors harbouring $n u c$ were then transformed into $L$. lactis NZ9000 harbouring pNZint, and the positive integrants which would obtain erythromycin resistance were then tested for their stability to stay integrated in the attB site of the genome. After 100 generations grown in nonselective conditions, all random colonies chosen which were sub-cultured on to erythromycin plates had positive growth, indicating that the integrated plasmid was still inside and has not been excised. In addition, PCR using the attB flanking primers (F-attB/R-attB) on genomic DNA extracted from the integrants further confirmed presence of the integrated plasmid.

Figure 2 (a) and (b) show an example of PCR verification of selected integrants using primers flanking the attB site on the genome after 100 generations with the expected DNA size of $3944 \mathrm{bps}, 3834 \mathrm{bps}, 3927 \mathrm{bps}$ and 3902 bps for pS1-4nuc, respectively, whereby the empty genomic DNA (negative control) was 300 bps. Figure 3 shows the gel electrophoresis image of the PCR amplified integrated surface displayed integrative plasmids 


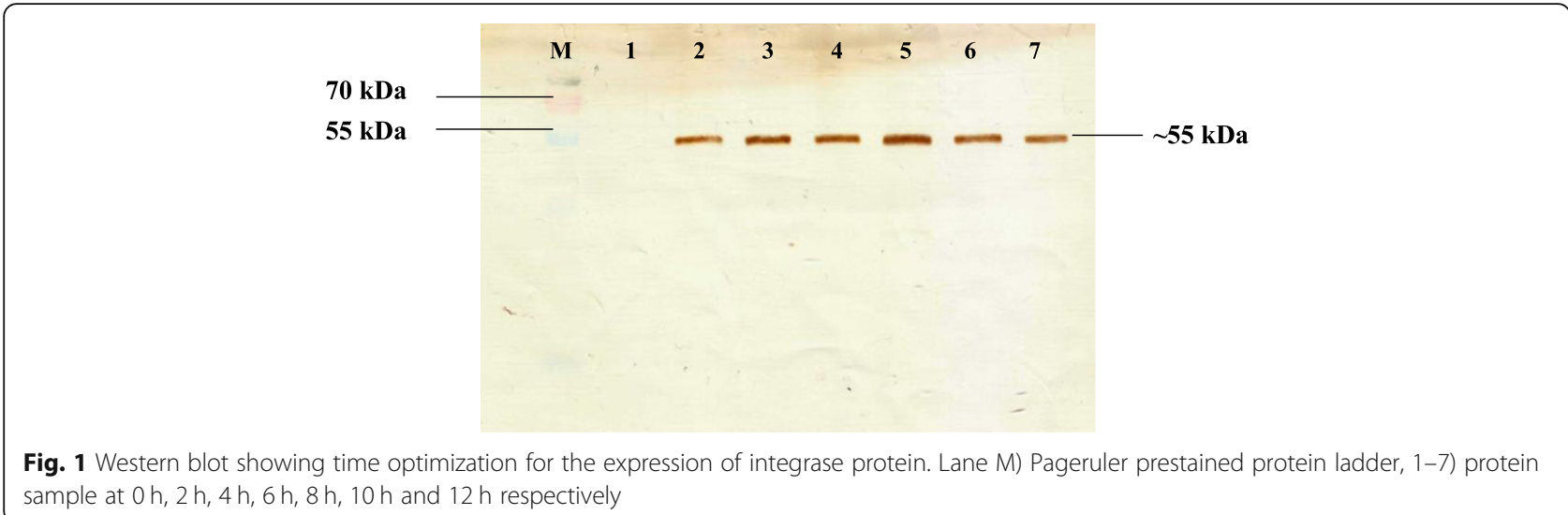

(pSD1nuc, pSD2nuc, pSD3nuc, and pSD4nuc) with the expected DNA size of $4916 \mathrm{bps}, 4875 \mathrm{bps}, 4912 \mathrm{bps}$ and 4943 bps respectively. However, some unspecific bands were also observed which is probably due to unspecific binding of the flanking primers in the genome

\section{Nuclease expression}

The secreted nuclease from the integrated secretion plasmids were determined by Toluidine Blue DNA (TBD) assay through colony overlay method as described by Lachica et al., (1971) [38]. The L. lactis strains harbouring integrated $n u c$ were observed to form bright pink halo zone as compared to the negative control, a non-integrated L. lactis. Figure 4 shows the representation of halo zone formed around the bacteria culture on the TBD plate. The TBD assay concluded that L. lactis integrated with pS4nuc (driven by $P_{\text {nisa }}$ promoter and SPK1 signal peptide) has the highest Nuc secretion with mean $0.575 \mathrm{~cm}$ followed by pS2nuc, pS3nuc and pS1nuc with mean $0.50 \mathrm{~cm}, 0.25 \mathrm{~cm}, 0.20 \mathrm{~cm}$ respectively (Fig. 5, raw data set in Additional file 1: Table S1). The ANOVA test indicates there is no significant difference in the expression of Nuc driven by $P_{170}$ and $P_{\text {nisa }}$ promoters. However, SPK1 showed better secretion of Nuc compared to USP45-LEISSTCDA fusion with significance of $P$-value $<0.05$.

\section{Immunofluorescence analysis}

The surface displayed nuclease on L. lactis NZ9000 was analysed to determine the bio-functionality of the cell wall anchoring motif, PrtP, an LPXTG anchoring system, via immunofluorescence microscope. It was observed that $L$. lactis integrated with pSDnuc1-4 were able to translocate and anchor the expressed Nuc onto the surface of the bacteria proven by the emission of green fluorescence signals as compared to the negative control, a non-integrated L. lactis (Fig. 6).

\section{Whole cell ELISA assay}

Quantitative expression of surface anchored nuclease was analysed by whole-cell ELISA assay with nuclease specific antibody. Among the surface displayed vector constructs, strain harbouring pSD1nuc showed extremely low signals, almost as low as the controls while pSD2-4nuc have almost the same signals intensities with no significance difference. Although it was observed that pSD1nuc and pSD3nuc strains driven by $P_{170}$ and $P_{\text {nisA }}$ promoter, respectively, show a highly significant difference with the latter showing greater signal intensities.

Table 1 Summary of secretion and surface display integrative vector components

\begin{tabular}{lllllll}
\hline Plasmid constructs & Size $(\mathrm{bps})$ & Promoter & Signal peptide & Propeptide & LPXTG anchor domain & Function \\
\hline pS1 & 3111 & $P_{170}$ & USP45 & LEISSTCDA & - & Secretion \\
pS2 & 3072 & $P_{170}$ & SPK1 & - & - & Secretion \\
pS3 & 3144 & $P_{\text {nisA }}$ & USP45 & LEISSTCDA & - & Secretion \\
pS4 & 3086 & $P_{\text {nisA }}$ & SPK1 & - & - & Secretion \\
pSD1 & 4152 & $P_{170}$ & USP45 & LEISSTCDA & PrtP $_{344}$ & Surface display \\
pSD2 & 4107 & $P_{170}$ & SPK1 & - & PrtP $_{344}$ & Surface display \\
pSD3 & 4185 & $P_{\text {nisA }}$ & USP45 & LEISSTCDA & PrtP & Surface display \\
pSD4 & 4146 & $P_{\text {nisA }}$ & SPK1 & - & PrtP $_{344}$ & Surface display \\
\hline
\end{tabular}



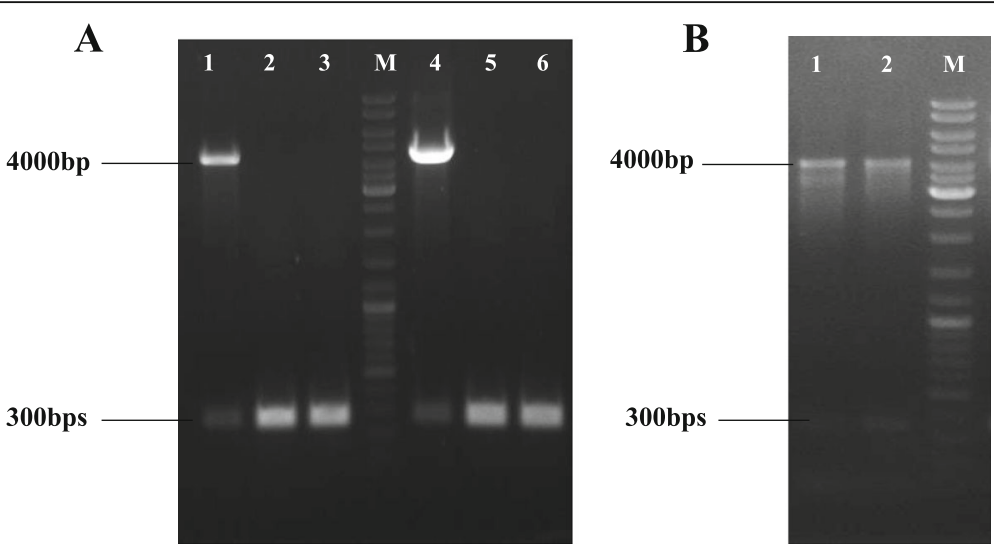

Fig. 2 PCR verification of integrated plasmid in the L. lactis genome using attB flanking primers. a M) Generuler DNA ladder mix 1) integrated pS1 nuc plasmid, 2) false positive clones, 3) negative control; 4) integrated pS2nuc plasmid, 5) false positive clone, 6) negative control. b 1) integrated pS3nuc, 2) integrated pS4nuc, M) Generuler DNA ladder mix

We cannot conclude that $P_{\text {nisA }}$ is a stronger promoter for surface displaying of proteins than $P_{170}$ as this result was not consistent when comparing pSD2 and pSD4. Similarly, inconclusive results were also observed on the surface display of nuclease controlled by USP45 and SPK1 signal peptides as pSD1nuc and pSD2 showed significant intensity differences while pSD3 and pSD4 did not. Therefore, we can only conclude that the combination of $P_{170}$ with USP45 was inferior compared to the

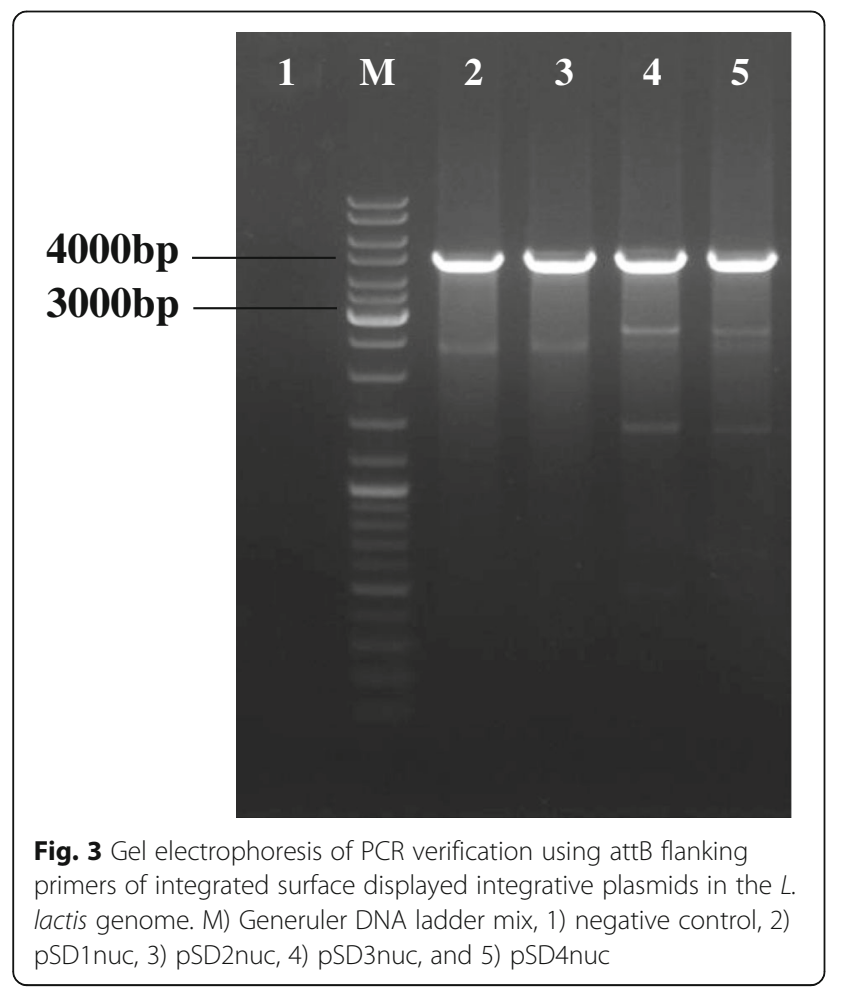

other systems in the surface display integrative vectors (Fig. 7, raw data set in Additional file 2: Table S2).

\section{Discussion}

In this work, two types of Lactococcus lactis integrative vectors utilizing the bacteriophage TP901-1 integrating system were successfully constructed. The TP901-1 is a temperate bacteriophage that resembles resolvase recombination mechanism. The TP901-1 attB was found to be located in a putative open reading frame encoded for competence protein, ComGC (Accession number: DJ61374.1) [39]. The integrative plasmid carrying the attP site recombines with the bacteria's DNA sequence

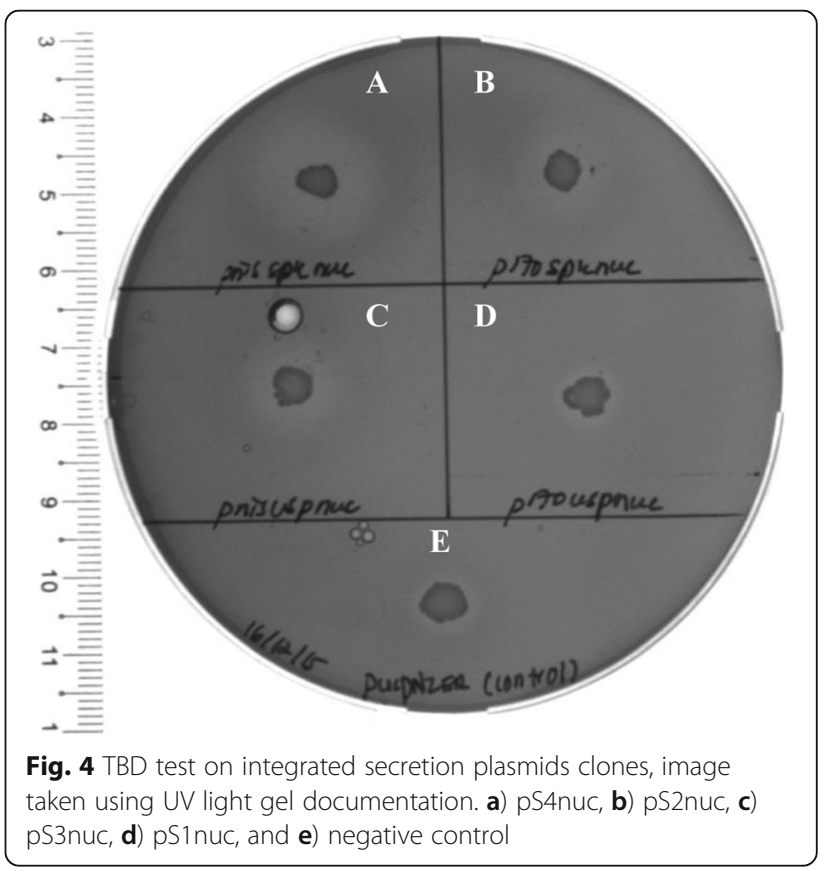




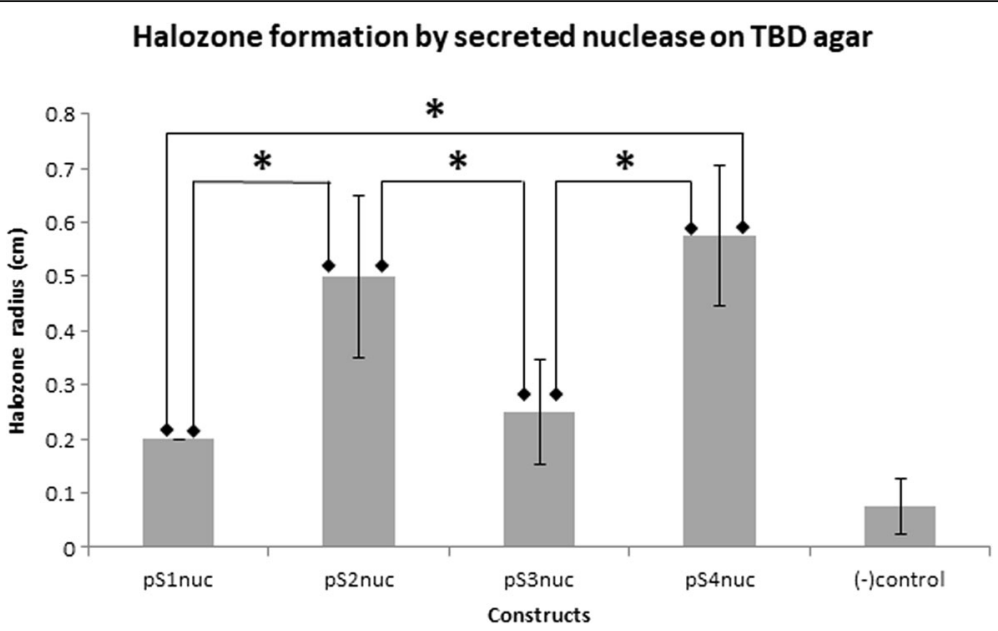

Fig. 5 TBD assay of secreted nuclease by L. lactis harbouring integrated nuc. Data shown is an average of the radius of halozone of three replicates and *indicates significance $P<0.05$. All samples are significant compared to the negative control

on the attB site, disrupting the open reading frame. However, up to date, there is no reports regarding the effect of this ORF disruption on the physiology of the cells [39, 40]. Bacillus subtilis, a naturally competent bacterium, utilises the proteins to take up of extracellular DNA into the cell. However, L. lactis and other dairy isolated bacteria were reported to be unable to take foreign DNA into the intracellular environment naturally. Thus, disruption of the protein might not have any significant effect.

The site-specific integrating system was designed to integrate the desired plasmid into L. lactis genome and express the gene of interest into the extracellular environment, where it is either fully secreted into the medium or surface displayed on L. lactis cell wall. The secretion integrative vectors, $\mathrm{pS}$ and the surface display integrative vectors, $\mathrm{pSD}$ were engineered with different combinations of promoters and signal peptides; $P_{170}$ versus $P_{\text {nisA }}$, and USP45 fused with LEISSTCDA versus SPK1 signal peptides alone, resulting in $\mathrm{pS} 1, \mathrm{pS} 2, \mathrm{pS} 3$ and $\mathrm{pS} 4$ secretion integrative vectors, and, pSD1, pSD2, pSD3 and pSD4 surface display integrative vectors, respectively (Table 2). Nuclease was used as a reporter to determine the ability of the bacteriophage integrating system to integrate into the L. lactis genome and the best combination of vector constructs to secrete or surface display the desired protein.

The data obtained showed that all the integrative vectors constructed were able to integrate into the genomic DNA of $L$. lactis and the integrants were stably integrated in the host genome. However, in this study, only PCR was used to verify integration of the plasmid. Further verification of the integration could possibly employ an alternative method which may include whole genome-sequencing to confirm that integration has taken place at the expected site and that ectopic integration has not taken place. However, it is unlikely that ectopic integration has taken place in the current study as the mechanism for integration using the attP/attB site is very specific, unlike homologous recombination where recombination may occur at different positions depending on the degree of similarity of the sequences.

The integrants constructed in this study were able to either secrete or surface display the reporter protein. The secreted Nuc results showed that pS2nuc and pS4nuc gave the highest secretion based on the radius of halo zone on TBD agar plates. Both pS2 and pS4 were driven by SPK1 signal peptide which demonstrated that the SPK1 signal peptide was superior over USP45 even though the USP45 was fused with synthetic propetide LEISSTCDA which was reported to enhance protein secretion [43]. This is despite USP45 being an endogenous signal peptide and the most commonly used signal peptide for secretion of heterologous protein in L. lactis. On the other hand, SPK1 is a signal peptide isolated from Pediococcus pentasoceus which was previously shown to possess comparative secretion efficiency to USP45 although total protein was at times much lower than in USP45 [44, 45].

From the analysis, there was no significant difference on the Nuc expression controlled by $P_{\text {nisa }}$ and $P_{170}$ promoters where the $P$-value for both pS1 against pS3 and pS2 against pS4 were above 0.05 . Therefore, we can conclude that $P_{\text {nisA }}$ and $P_{170}$ promoters have comparable strength although the data showed a slight increase in the expression of Nuc by $P_{\text {nisa }}$ promoter. The wellestablished NICE system with $P_{\text {nisa }}$ is known for its strong and tightly regulated promoter [46-48] induced by nisin, whereas $P_{170}$ is a lactococcal auto-inducible promoter by the accumulation of lactic acid in the 

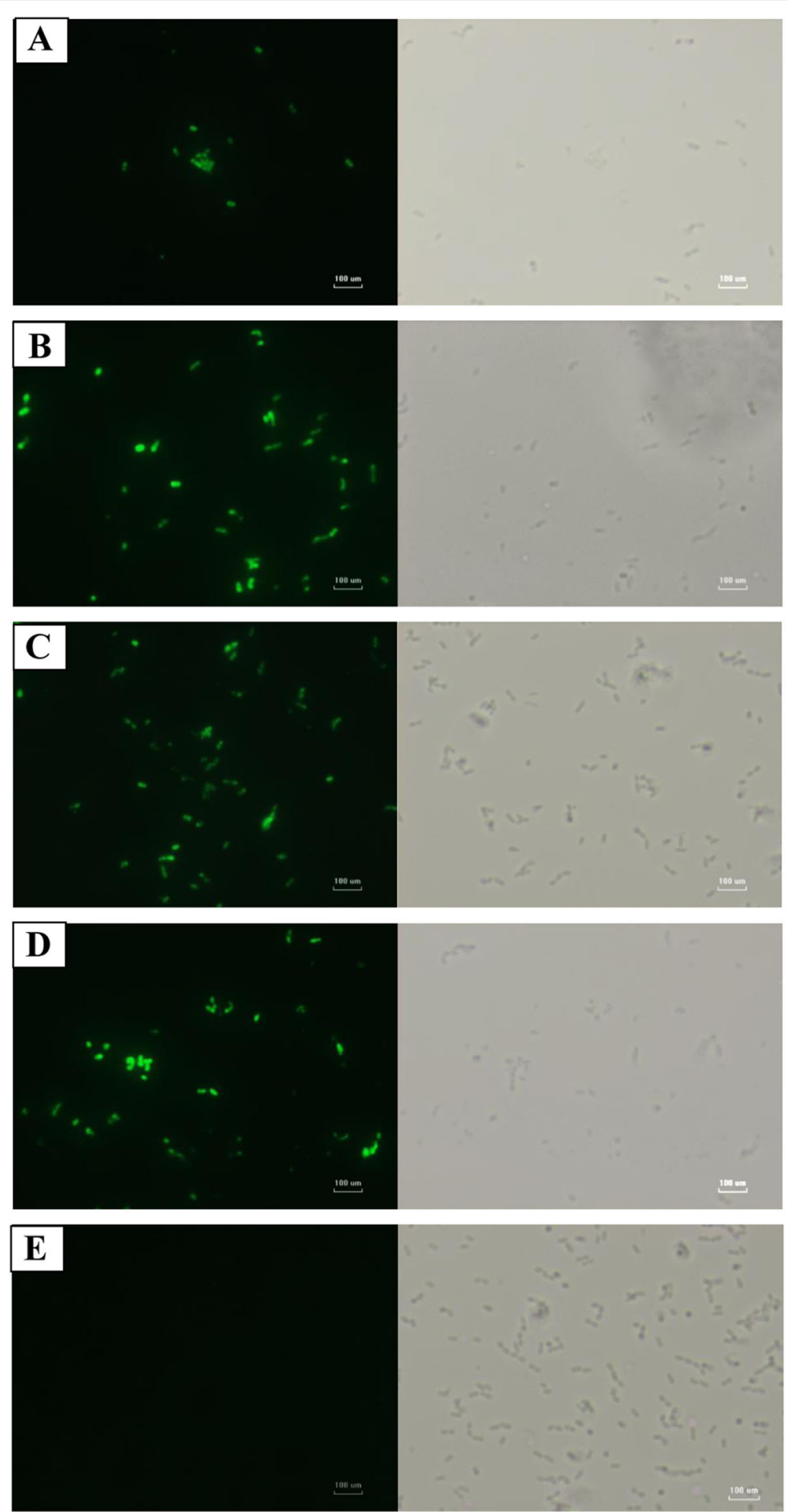

Fig. 6 Fluorescent microscopy of L. lactis harbouring integrated pSDnuc1-4. The fluorescence images indicate surface anchored nuclease protein expressed from integrated plasmids; Left Panel: Green filter, Right Panel: Phase contrast; a pSD1nuc, b pSD2nuc c pSD3nuc, d pSD4nuc and nonintegrated L. lactis NZ9000 as negative control (e)

culture medium which has the potential to be used in food-grade expression system [49-51]. In the industrial application where nisin induction will be costly for mass production and the safety concern of nisin in pharmaceutical applications made $P_{170}$ promoter as a good alternative. 


\section{Whole-cell ELISA of surface displayed nuclease on L. lactis}

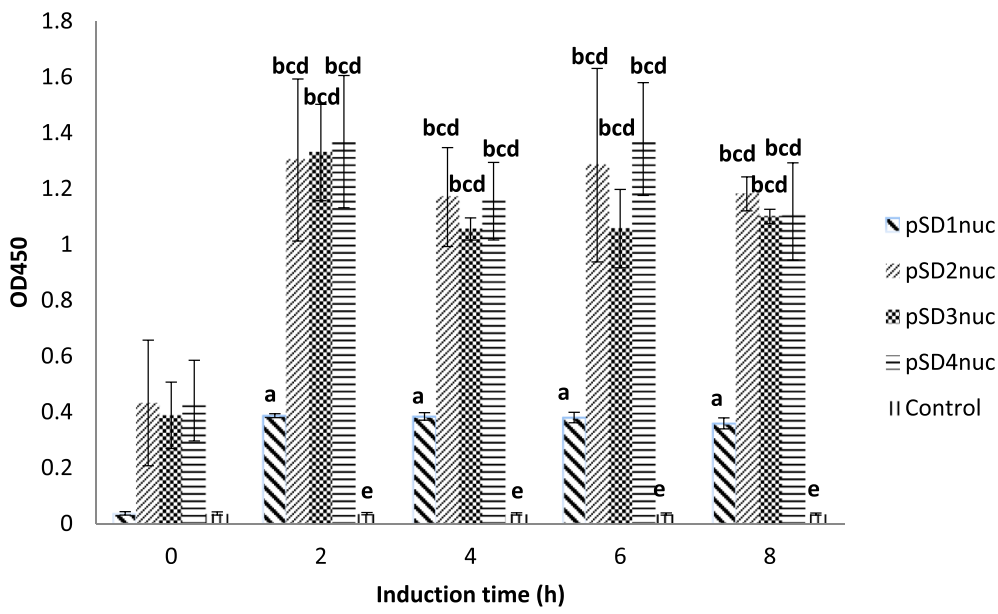

Fig. 7 Whole-cell ELISA of induction time optimisation (from 0 to $8 \mathrm{~h}$ induction) for surfaced displayed nuclease on different integrated L. lactis constructs. ${ }^{\text {abcde }}$ common letter on the bars mean no significance difference on the expression of nuclease by the respective integrative vectors $(P<0.05)$

Table 2 Bacterial strains and plasmids used in this study

\begin{tabular}{|c|c|c|}
\hline Strain or plasmid & Relevant phenotypes & References \\
\hline \multicolumn{3}{|l|}{ Strains } \\
\hline E. coli Top 10 & & Invitrogen \\
\hline L. lactis NZ9000 & MG1363 pepN::nisRK, host strain for all lactococcal plasmids & [41] \\
\hline L. lactis pNZint & L. lactis harbouring pNZint plasmid & This study \\
\hline \multicolumn{3}{|l|}{ Plasmid } \\
\hline pCRTM-Blunt II-TOPO ${ }^{\oplus}$ & Zero Blunt ${ }^{\oplus} \mathrm{TOPO}^{\circledast} \mathrm{PCR}$ cloning Kit & Invitrogen \\
\hline pUC19 & 2686 bps, Amp ${ }^{R}$, Cloning vector & New England Biolabs Inc. (NEB) \\
\hline pNZ8048 & $3348 \mathrm{bps}, \mathrm{Cm}^{\mathrm{R}}$, Nisin inducible expression vector & [41] \\
\hline pMG36e & 3611 bps, Erm ${ }^{R}$ & [42] \\
\hline pNZSPKNuc & Modified pNZ8048 carrying SPK1 signal peptide, nuc gene from S. aureus & Microbial Biotech Lab, UPM \\
\hline pNZ170Gus & Modified pNZ8008, $P_{\text {nisA }}$ was replaced with $P_{170}$ & Microbial Biotech Lab, UPM \\
\hline pNZint & Modified pNZ8048 carrying integrase gene of TP901-1 & This study \\
\hline${ }^{a} \mathrm{pS} 1$ & $\begin{array}{l}\text { Secretion integrative vector harboring attP of T901-1, } P_{170} \text {, E. coli rep origin, } \\
\text { USP45-LEISSTCDA, Em }\end{array}$ & This study \\
\hline${ }^{\mathrm{a} p S 2}$ & Secretion integrative vector harboring attP of T901-1, $P_{170}$, E. coli rep origin, SPK1, Em ${ }^{R}$ & This study \\
\hline${ }^{a} \mathrm{p} S 3$ & $\begin{array}{l}\text { Secretion integrative vector harboring attP of T901-1, } P_{\text {nisA }}, E \text {. coli rep origin, } \\
\text { USP45-LEISSTCDA, Em }{ }^{R}\end{array}$ & This study \\
\hline${ }^{a} \mathrm{pS} 4$ & Secretion integrative vector harboring attP of T901-1, $P_{\text {nisA, }}$ E. coli rep origin, SPK1, Em ${ }^{R}$ & This study \\
\hline${ }^{a}$ pSD1 & $\begin{array}{l}\text { Surface display integrative vector harboring attP of T901-1, } P_{170} \text {, E. coli rep origin, } \\
\text { USP45-LEISSTCDA, PrtP anchor domain, Em }{ }^{R}\end{array}$ & This study \\
\hline apSD2 & $\begin{array}{l}\text { Surface display integrative vector harboring attP of T901-1, } P_{170} \text {, E. coli rep origin, SPK1, } \\
\text { PrtP }_{344} \text { anchor domain, } \mathrm{Em}^{R}\end{array}$ & This study \\
\hline${ }^{\mathrm{a} p S D 3}$ & $\begin{array}{l}\text { Surface display integrative vector harboring attP of T901-1, } P_{\text {nisA }}, E \text {. coli rep origin, } \\
\text { USP45-LEISSTCDA, PrtP }_{344} \text { anchor domain, Em }\end{array}$ & This study \\
\hline${ }^{a}$ pSD4 & $\begin{array}{l}\text { Surface display integrative vector harboring attP of T901-1, } P_{\text {nisA, }} \text {. E. coli rep origin, } \\
\text { SPK1, PrtP } 344 \text { anchor domain, Em }{ }^{R}\end{array}$ & This study \\
\hline
\end{tabular}

\footnotetext{
${ }^{\text {a }}$ Plasmids had variations where nuclease reporters were cloned into the MCS and denoted with suufix-nuc in text
} 
In the case of surface display integrative vectors, $\mathrm{pSD}$, the integrated $n u c$ was successfully expressed and anchored on the cell wall of L. lactis as shown in the immunofluorescence images (Fig. 6). The anchor domain $\operatorname{PrtP}_{344}$, which has the well-known LPXTG cell wall anchoring motif, successfully anchored the Nuc onto the surface of L. lactis [52-54]. Whole cell ELISA assay showed that pSD1nuc which had the combination of $P_{170}$ promoter with USP45 signal peptide gave very low signals in the ELISA assay, although fluorescent signals were still detectable in immunofluorescence assay (Fig. 7). The expressed Nuc on the other clones which harboured pSD2nuc, pSD34nuc and pSD4nuc were comparable, although pSD2nuc and pSD4nuc, both which had the signal peptide SPK1 gave slightly better signals, although values were non-significant.

\section{Conclusions}

In conclusion, the synthetic integrative vectors constructed in this study based on site-directed recombination via the attP/attB site were able to integrate the vectors into the lactococcal chromosome facilitated by integrase enzyme. The secretion integrative vectors, $\mathrm{pS} 1$, $\mathrm{pS} 2, \mathrm{pS} 3$ and pS4 were able to secrete Nuc protein into the extracellular region, while surface displayed integrative vectors; pSD1, pSD2, pSD3 and pSD4 were able to display Nuc reporter protein on the cell wall via the $\operatorname{PrtP}_{344}$ anchor domain. SPK1 signal peptide was shown to be superior over USP45 in secretion while the combination of $P_{170}$ and USP45 was consistently inferior in both secretion and surface display integrative vectors. These constructed integrative expression vectors can be used to secrete and surface display recombinant protein and polypeptides stably for various applications, especially in live vaccine delivery.

\section{Methods}

\section{Bacterial strains, plasmid and culture conditions}

Escherichia coli Top 10 (Invitrogen, USA) cells were grown at $37{ }^{\circ} \mathrm{C}$ with agitation $(250 \mathrm{rpm})$ in Luria Bertani (LB) broth or LB agar (Merck) (1.5\% w/v bacteriological agar) with $50 \mu \mathrm{g} / \mathrm{ml}$ of kanamycin, $100 \mu \mathrm{g} / \mathrm{ml}$ of ampicillin or $75 \mu \mathrm{g} / \mathrm{ml}$ of erythromycin when necessary. Lactococcus lactis subsp. cremoris NZ9000 (MoBiTech $\mathrm{GmbH}$, Germany) was grown in M17 (Merck) broth or agar supplemented with $0.5 \%(\mathrm{w} / \mathrm{v})$ glucose as standing culture at $30{ }^{\circ} \mathrm{C}$. Whenever required, erythromycin $(10 \mu \mathrm{g} / \mathrm{ml})$ and chloramphenicol $(7.5 \mu \mathrm{g} / \mathrm{ml})$ were used for the selection of recombinant L. lactis cultures. E. coli transformation was carried out using $\mathrm{CaCl}_{2}$ method [55] while L. lactis competent cell preparation and transformation were performed according to the protocol described by [56]. The electroporated cells were grown in SGM17 broth containing $0.5 \%(\mathrm{w} / \mathrm{v})$ glucose and $0.5 \mathrm{M}$ sucrose supplemented with chloramphenicol and/or erythromycin at a final concentration of $7.5 \mu \mathrm{g} / \mathrm{ml}$ and $10 \mu \mathrm{g} / \mathrm{ml}$ respectively and incubated at $30^{\circ} \mathrm{C}$ for 2 days.

All plasmids used and developed in this study are listed in Table 2. L. lactis NZ9000 was used as the host for site-specific integration, providing the chromosomal attB site for the lactococcal phage TP901-1. NZ9000 was transformed in advanced with pNZint, which is a modified pNZ8048 harbouring the integrase gene (int), encoding the TP901-1 integrase (Genbank accession number: AF304433.1), to facilitate site-specific recombination. The constructed secretion integrative vectors $\mathrm{pS} 1, \mathrm{pS} 2, \mathrm{pS} 3, \mathrm{pS} 4$ and surface display integrative vectors pSD1, pSD2, pSD3, pSD4 are suicide vectors harbouring the $P_{170}$ promoter or $P_{\text {nisA }}$, USP45-LEISSTCDA or SPK1 signal peptide, MCS, TP901-1 attP site, E. coli origin of replication, erythromycin resistance gene $\left(\mathrm{Em}^{\mathrm{R}}\right)$. The integrative vectors were then transformed into the earlier L. lactis NZ9000 harbouring pNZint which is subsequently integrated into the attB site of the host genome.

\section{PCR amplifications and DNA manipulations}

PCR amplification procedures were performed using either Taq DNA polymerase, for analytical purposes, or $P f u$ DNA polymerase, for cloning and sequencing (Fermentas, USA). The integrated DNA was verified via PCR with KOD FX Neo (TOYOBO, Japan). PCR primers were designed based on the known DNA sequences and relevant restriction enzymes (RE) were introduced via primers when needed (Table 3) which were synthesized by Integrated DNA Technologies (Singapore). DNA fragments were purified using GeneJET PCR purification Kit and GeneJET Gel Extraction Kit (Thermofisher, USA). Plasmids were isolated using Favorpep ${ }^{\text {Tw }}$ Plasmid DNA Extraction Mini Kit (Favorgen, Taiwan). Conventional and FastDigest RE and T4 DNA ligase were obtained from Thermofisher, USA.

\section{Plasmid constructions}

The respective genes and DNA fragments were PCR amplified using primers listed in Table 3 . The integrative vectors were constructed based on the pNZ8048 plasmid as backbone. A cassette consisting of USP45 fused with LEISSTCDA propeptide to increase secretion efficiency, pNZ8048 multiple cloning sites (MCS) modified to include more RE sites, pNZ8048 terminator $(\mathrm{T})$, and TP901-1 bacteriophage attachment site (attP) was synthesized by Integrated DNA Technologies (Singapore) and denoted as attP cassette.

The vectors constructions strategy was divided into four phases; Phase I) Construction of PZatt cassette composed of the $P_{170}$ promoter, USP45 signal peptide, LEISSTCDA propeptide and attP sequence; Phase II) Construction of the secretion integrative vectors ( $\mathrm{pS} 1-$ 
Table 3 Primers used in this study

\begin{tabular}{|c|c|c|}
\hline Primers & Sequences & RE \\
\hline F-attB & CTACTGCTGCTTCACCAGTTT & - \\
\hline R-attB & GTATGCAGCGATGTTGTTACCC & - \\
\hline F-attP & GGAC CTCGAGTCCAACTCGCTTAATTGC & Xhol \\
\hline R-attP & GGACGGATCCGCTAAAACGTCTCAGAAA & BamHI \\
\hline F-Int & GACGCCATGGCACATCATCATCATCATCATATGACTAAGAAAGTAGCAATCTATAC & Ncol \\
\hline R-Int & GCACGAGCTCTTAAGCGAGTTGGAATTTAAATATG & Hindlll \\
\hline F-PnisA & GCGAGATCTAGTCTTATAACTATAC & Bglll \\
\hline R-PnisA & GCAGATATCGTGAGTGCCTCCTTATAAT & EcoRV \\
\hline F-P170 & GCGACAGATCTGAACTATGAATATC & Bglll \\
\hline R-P170 & GCACGATATCAACTGTTCTTTTTIAATTTTT & EcoRV \\
\hline F-USP45 & GACGGATATCATGAAAAAAAAGA & EcoRV \\
\hline R-USP45 & CTGAGTCGACGATATTCGAGAGC & Sall \\
\hline F-SpkNuc & GCGTGATATCATGAAAAAAATATTAACGTTGGTAT & EcoRV \\
\hline R-NucH & GGCGAGCTCTTAGTGGTGATGATGGTGA & Sacl \\
\hline F-NucEV & GCGTGATATCATGAAAAAAATATTAACGTTGGTAT & EcoRV \\
\hline F-NucNI & CGAGCCATGGCTATGAAAAAAATATTAACG & Ncol \\
\hline R-NucEl & CGCGGAATTCTTGACCTGAATCAGCGTTGTCTTCG & EcoRl \\
\hline F-Em & GACGGGATCCAATCAGGCTTGATCCCCAGTAAGTC & BamHI \\
\hline R-Em & GACGAGATCTAGGATGAGGAGGCAGATTGCCTTG & Bglll \\
\hline F-PrtP344 & GAGCGAATTCTGGCTCTAGAGGATCCAAGTC & EcoRl \\
\hline R-PrtP344 & TAAACTATGCGGCCGCGACAGGCTATTCTTC & Notl \\
\hline F-E. coli Ori & GGAGGGATCCGGCGTAATCATGGTCATAG & BamHI \\
\hline R-E. coli Ori & AGGCGGATCCCTGTCAGACCAAGTTTACTC & BamHI \\
\hline
\end{tabular}

RE sites are in bold

4); (a) Plasmid circularisation by incorporation of erythromycin resistant gene and $E$. coli replication origin into the PZatt cassette, denoted as pS1; (b) Replacement of $P_{170}$ promoter with $P_{\text {nisa }}$ promoter to produce $\mathrm{pS} 3$ plasmid; (c) Replacement of USP45-LEISSTCDA fusion with SPK1 signal peptide into each pS1 and pS3 plasmids to produce $\mathrm{pS} 2$ and $\mathrm{pS} 4$ plasmids (Additional file 3: Figure S1); Phase III) Construction of the surface display integrative vectors (pSD1-4) by incorporation of $\mathrm{PrtP}_{344}$ anchor domain into each secretion integrative vector; Phase IV) Cloning of reporter gene, nuclease (Additional file 4: Figure S2).

In Phase I, the attP cassette was ligated with $P_{170}$ promoter to produce the PZatt cassette through EcoRV RE. In Phase II (a), the PZatt cassette was ligated with the erythromycin resistant gene $\left(\mathrm{Em}^{\mathrm{R}}\right)$ that was isolated from pMG36e to produce the PZER cassette using BglII RE. The PZER cassette was then fused with colE1 origin of replication from the pUC19 plasmid via BamHI RE to produce the functional circular plasmid, denoted as pS1. At each step of cassette construction, the cassettes were subcloned into pCRTM-Blunt II-TOPO ${ }^{\circ}$ for maintenance. The $P_{170}$ promoter of pS1 was cleaved out using BglII and
EcoRV and was substituted with a similarly digested $P_{\text {nisA }}$ promoter to produce pS3 plasmid (Phase II-b). On the other hand, the pS2 plasmid was constructed by replacing USP45 signal peptide with SPK1 using EcoRV and KpnI RE. To construct pS4 plasmid, USP45 in pS3 plasmid was cleaved out and was replaced with SPK1 signal peptide using NcoI and KpnI RE (Phase II-c). These resulted in secretion integrative plasmids ( $\mathrm{pS} 1-4)$ constructs.

The surface display integrative plasmids, pSD1-4 were constructed by insertion of PCR amplified PrtP $\mathrm{P}_{344}$ into the respective secretion integrative vectors using EcoRI and NotI RE. All the successfully constructed integrative vectors were inserted with nuclease reporter gene, nuc in the MCS via NcoI and EcoRI sites to determine the functionality of the plasmids and to analyse the level of expression of each integrative vectors. Separately, the helper vector, pNZint (plasmid carrying integrase gene to assist integration) was constructed by cloning the integrase gene into pNZ8048 plasmid using NcoI and SacI RE.

\section{Cloning and integration of nuclease gene}

The integration of foreign DNA into the host genome only happens with the presence of the integrase protein. 
Thus, L. lactis NZ9000 competent cells were first transformed with pNZint helper plasmid and the positive transformants were verified by restriction enzyme digestion and sequencing. The integration of the newly constructed integrative vectors harbouring the nuclease reporter was conducted in a few steps. First, L. lactis NZ9000 harbouring pNZint was made competent using protocol described by Holo and Nes (1989) with addition of $7.5 \mu \mathrm{g} / \mathrm{ml}$ of chloramphenicol into the culture media. Next, the competent cells were transformed with each integrative vector constructed according to the mentioned protocol with minor modifications. During the transformation process, after an hour of incubation, $20 \mathrm{ng} / \mathrm{ml}$ of nisin was added into the transformants to allow the expression of integrase protein and integration of the plasmid harbouring the nuclease gene. Transformants were then plated on SGM17 agar plate supplemented with $10 \mu \mathrm{g} / \mathrm{ml}$ of erythromycin and incubated at $30{ }^{\circ} \mathrm{C}$ for $2-3$ days. The colonies were then verified with PCR using attB flanking primers (F-attB and RattB) and were sent for sequencing. The positive colonies were used for further analysis.

\section{Stability tests}

Doubling time of L. lactis was first determined using the L. lactis growth profile which was plotted prior. From the doubling time, cells were grown up to 100 generations by subculturing the cells to fresh media before it reaches stationary phase. After roughly 100 generations, cells were plated onto non-selective GM17 media. Then, colonies were transferred onto selective GM17 media containing $10 \mu \mathrm{g} / \mathrm{ml}$ of erythromycin due determine if the cells still possess antibiotic resistance. For further verification, genomic DNA was extracted from the integrants and verified using PCR with attB flanking primers to determine the presence of the integrated plasmid.

\section{Expression of heterologous protein}

The expressed heterologous protein was determined by Western blotting. The grown culture of L. lactis harbouring integrated $n u c$ was harvested. The secreted Nuc in the medium was harvested using 100\% trichloroacetic acid, TCA (Merck, Germany) and the cell pellet was sonicated to harvest intracellular Nuc. Briefly, the harvested protein was added with loading buffer and boiled for $10 \mathrm{~min}$. Treated samples were ran on SDSpolyacrylamide gel electrophoresis and then transferred to polyvinylidene difluoride (PVDF) membrane (ThermoFisher, USA). After blocking with $2 \%$ BSA at room temperature for $2 \mathrm{~h}$, the membrane was incubated with the nuclease specific primary antibody, Staphylococcus aureus anti-nuclease antibody (LSBio, USA) at 1:10000 dilution followed by a secondary antibody goat antirabbit IgG H\&L (HRP) (Abcam, USA) at 1:3000 dilution for another hour. The labelled protein on the membrane was detected using DAB substrate (Amresco, USA). On the other hand, the integrase protein was detected using 1:1000 dilution of primary antibody, Pierce ${ }^{\text {tw }} 6 \mathrm{X}$-His epitope tag antibody (ThermoFisher, USA) and 1:1000 dilution of secondary antibody, Peroxidase Conjugated Affinity Purified Goat anti-Mouse IgG (OriGene, USA).

\section{Nuclease assay (TBD assay)}

Toluidine Blue DNA Agar was used for the detection of thermostable deoxyribonuclease activity. The agar was prepared according to the manufacturers protocol (HiMedia, India). Nuclease activity was detected using colony overlay as described by Lachica et al. (1970) [38] with minor modifications. L. lactis strain harboring nuc gene was spotted into the Brain Heart Infusion (BHI) agar (Oxoid, UK) and incubated overnight at $30^{\circ} \mathrm{C}$. Then, $15 \mathrm{ml}$ of boiled TBD agar that has been cooled to $50{ }^{\circ} \mathrm{C}$ was poured onto the overnight cultured $\mathrm{BHI}$ agar. The overlaid agar was incubated at $37^{\circ} \mathrm{C}$ for $4 \mathrm{~h}$ and bright pink halos observed.

\section{Immunofluorescence microscopy analysis}

Cell wall anchoring protein was determined by immunofluorescence microscopy based on fluorescence conjugated secondary antibody tagging. The bacteria suspected to surface display nuclease were harvested, washed with PBS, applied to microscope slides, and fixed with $4 \%(\mathrm{v} / \mathrm{v})$ formaldehyde. The cells were blocked with $3 \%(\mathrm{w} / \mathrm{v})$ of BSA for $30 \mathrm{~min}$ at RT and washed thrice. The slides were incubated for $1 \mathrm{~h}$ with anti-nuclease antibody (diluted in 1:500 in PBS and 1\% BSA) (LSBio, USA) on a slide chamber at RT, washed thrice with PBS. Then, the cells were labelled with polyclonal antinuclease primary antibody raised in rabbit (LSBio, USA) at 1:500 dilution and incubated for $1 \mathrm{~h}$ at RT. The slide was washed thrice with $1 \mathrm{X}$ PBS for $10 \mathrm{~min}$ and then incubated with anti-rabbit secondary antibody conjugated with Alexa Fluor 488 (Merck, USA) at 1:1000 dilution with $1 \mathrm{~h}$ incubation at RT followed by washing. The samples were analysed using Zeis Confocal Microscope (Carl Zeis, Germany) fixed with green filter.

\section{Whole cell ELISA assay}

The anchored recombinant protein was quantified using ELISA assay with the specific antibody. The overnight cultures were transferred into fresh media and incubated at $30^{\circ} \mathrm{C}$ until reached $\mathrm{OD}_{600} 0.5$ and was induced with $20 \mathrm{ng} / \mathrm{ml}$ nisin. The cultures were harvested and normalized at constant $\mathrm{OD}_{600}$. They were then fixed with $4 \%$ (w/v) paraformaldehyde at RT, washed with $1 \mathrm{X}$ PBS and then blocked with $3 \%(\mathrm{w} / \mathrm{v})$ BSA before washed again. The cells were then incubated with primary polyclonal nuclease anti-rabbit antibody (LSBio, USA), washed and 
then incubated with HRP conjugated secondary antirabbit antibody (Abcam, USA). The treated cells were transferred into 96 wells plate and incubated with substrate at $\mathrm{RT}$ in the dark. The reactions were stopped with $1 \mathrm{M} \mathrm{H}_{2} \mathrm{SO}_{4}$ (Sigma, USA). The samples were then analysed using ELISA reader at $\mathrm{OD}_{450}$ (Magellan for F50, USA).

\section{Supplementary information}

Supplementary information accompanies this paper at https://doi.org/10. 1186/s12896-019-0575-x.

Additional file 1: Table S1. Data set of TBD assay of secreted nuclease. Additional file 2: Table S2. Data set of whole-cell ELISA of surface displayed nuclease.

Additional file 3: Figure S1. Schematic representations of the construction strategy of the integrative vectors. Phase I) constructions of PZatt cassette backbone; Phase II) construction of secretion integrative vectors, (a) pS1 plasmid, (b) pS3 plasmid, (c) pS2 and pS4.

Additional file 4: Figure S2. Schematic representations of the construction strategy the integrative vectors. Phase III) construction of surface display integrative vectors, (pSD1-4); Phase IV) cloning of nuc gene into each integrative vectors.

\section{Abbreviations}

ANOVA: Analysis of variance; attB: Bacteria attachment site; attP: Phage attachment site; ELISA: Enzyme-linked immunosorbent assay; GRAS: Generally Recognised as Safe; LAB: Lactic Acid Bacteria; pS: Secretion integrative vector; pSD: Surface display integrative vector; RE: Restriction Enzyme; TBD: Toluidine Blue DNA

\section{Acknowledgements}

The authors wish to thank Nur Aqlili Riana Alias for providing the nuc gene.

\section{Authors' contributions}

IK designed the research, conducted the reported experiments, data analysis and wrote the manuscript. AAS assisted in the writing of the manuscript and data analysis. RAR proposed the research concept and assisted in design of experiments. MJM contributed in the experimental design. All authors read and approved the final manuscript.

\section{Funding}

This project was funded by Malaysian Ministry of Science, Technology and Innovation (02-01-04-SF1608). The funding body had no role in the design of the study, the collection, analysis, and interpretations of data and in writing the manuscript.

\section{Availability of data and materials}

All data generated or analysed during this study are included in this published article (and its supplementary information files).

\section{Ethics approval and consent to participate}

Not applicable.

\section{Consent for publication}

Not applicable.

\section{Competing interests}

The authors declare that they have no competing interests.

\section{Author details}

'Department of Cell and Molecular Biology, Faculty of Biotechnology and Biomolecular Sciences, University Putra Malaysia, 43400 UPM, Serdang, Selangor, Malaysia. ${ }^{2}$ Department of Microbiology, Faculty of Biotechnology and Biomolecular Sciences, University Putra Malaysia, 43400 UPM, Serdang, Selangor, Malaysia. ${ }^{3}$ Institute of Bioscience, University Putra Malaysia, 43400
UPM Serdang, Selangor, Malaysia. ${ }^{4}$ Chancellory, Universiti Teknikal Malaysia, 76100 Durian Tunggal, Melaka, Malaysia.

Received: 2 May 2019 Accepted: 7 November 2019

Published online: 27 November 2019

\section{References}

1. Song AAL, In LLA, Lim SHE, Rahim RA. A review on Lactococcus lactis: from food to factory. Microb Cell Factories. 2017:16:1-15.

2. Pontes DS, de Azevedo MSP, Chatel J-M, Langella P, Azevedo V, Miyoshi A. Lactococcus lactis as a live vector: heterologous protein production and DNA delivery systems. Protein Expr Purif. 2011;79:165-75.

3. Souza RD, Pandeya DR, Hong S. Review article Lactococcus Lactis : an efficient gram positive cell factory for the production and secretion of recombinant protein. Biomed Res. 2012;23:1-7.

4. Bahey-El-Din M, Gahan CGM, Griffin BT. Lactococcus lactis as a cell factory for delivery of therapeutic proteins. Curr Gene Ther. 2010;10:34-45.

5. Morello E, Bermúdez-Humarán LG, Llull D, Solé V, Miraglio N, Langella P, et al. Lactococcus lactis, an efficient cell factory for recombinant protein production and secretion. J Mol Microbiol Biotechnol. 2008;14:48-58.

6. Jannitire L, Niaudet B, Pierre E, Ehrlich SD. Stable gene amplification in the chromosome of Bacillus subtilis. Gene. 1985:40:47-55.

7. Mckay LL. Functional properties of plasmids in lactic streptococci. Antonie Van Leeuwenhoek. 1983:49:259-74.

8. Glick BR. Metabolic load and heterologous gene expression. Biotechnol Adv. 1995:13:247-61.

9. Martín MC, Pant N, Ladero V, Günaydin G, Andersen KK, Alvarez B, et al. Integrative expression system for delivery of antibody fragments by lactobacilli. Appl Environ Microbiol. 2011;77:2174-9.

10. Coddeville M, Ritzenthaler P. Control of directionality in bacteriophage mv4 site-specific recombination: functional analysis of the Xis factor. J Bacteriol. 2010;192:624-35.

11. Martin MC, Alonso JC, Sua JE, Alvarez MA, La P. Generation of food-grade recombinant lactic acid bacterium strains by site-specific recombination. Appl Environ Microbiol. 2000:66:2599-604.

12. Gosalbes MJ, Esteban CD, Luis J, Pérez-martínez G, Gala L. Integrative foodgrade expression system based on the lactose regulon of Lactobacillus casei. Appl Environ Microbiol. 2000;66:4822-8.

13. Iwanicki A, Pi I, Grela A, Łę T, Obuchowski M. A system of vectors for Bacillus subtilis spore surface display. Microb Cell Factories. 2014;13:1-9.

14. Stover BCK, Bansal GP, Hanson MS, Burlein JE, Palaszynski SR, Young JF, et al Protective immunity elicited by recombinant Bacille Calmette-Guerin ( BCG ) expressing outer surface protein a (OspA) lipoprotein : a candidate Lyme disease vaccine. J Exp Med. 1993:178:197-209.

15. Joseph J, Fern R, Cardona P, Mothe B, Gatell JM. Molecular characterization of heterologous HIV-1gp120 gene expression disruption in Mycobacterium bovis BCG host strain : a critical issue for engineering mycobacterial basedvaccine vectors. J Biomed Biotechnol. 2010:2010:357370.

16. Hatfull GF. Mycobacteriophages. Microbiol Spectr. 2018;6:1-32.

17. Van Kessel JC, Marinelli LJ, Hatfull GF. Recombineering mycobacteria and their phages. Perspectives (Montclair). 2008;6:851-7.

18. Murry J, Sassetti CM, Moreira J, Lane J, Rubin EJ. A new site-specific integration system for Mycobacteria. Tuberculosis. 2005;85:317-23.

19. Hook CD, Samsonov W, Ublinskaya AA, Kuvaeva TM, Andreeva EV, Gorbacheva LY, et al. A novel approach for Escherichia coli genome editing combining in vivo cloning and targeted long-length chromosomal insertion. J Microbiol Methods. 2016;130:83-91.

20. Zucca S, Pasotti L, Politi N, Gabriella M, De Angelis MG, Magni P. A standard vector for the chromosomal integration and characterization of BioBrick ${ }^{\text {TM }}$ parts in Escherichia coli. J Biol Eng. 2013;7:1-13.

21. Yeom S-J, Kim YJ, Lee J, Kwon KK, Han GH, Kim H, et al. Correction : longterm stable and tightly controlled expression of recombinant proteins in antibiotics-free conditions. PLoS One. 2017;12:e0175955.

22. Datta S, Costantino N, Court DL. A set of recombineering plasmids for gram-negative bacteria. 2006:379:109-15.

23. Sabri S, Steen JA, Bongers M, Nielsen LK, Vickers CE. HL HA2 Knock-in / Knock-out ( KIKO ) vectors for rapid integration of large DNA sequences, including whole metabolic pathways, onto the Escherichia coli chromosome at well-characterised loci. 2013;12:1-1.

24. Chung $M$, Yeh I, Sung L, Wu M, Chao Y. Enhanced integration of large DNA into E. coli chromosome by CRISPR / Cas9. Biotechnol Bioeng. 2017;114:172-83. 
25. Leenhouts KJ, Kok J, Venema G. Stability of integrated plasmids in the chromosome of Lactococcus lactis. Appl Environ Microbiol. 1990;56:2726-35.

26. Leenhouts KJ, JAN K, Venema G. Campbell-Like Integration of Heterologous plasmid DNA into the Chromosome of Lactococcus lactis subsp. lactis. Appl Environ Microbiol. 1989;55:394.

27. Chopin MC, Chopin A, Rouault A, Galleron N. Insertion and amplification of foreign genes in the Lactococcus lactis subsp. lactis chromosome. Appl Environ Microbiol. 1989;55:1769-74

28. Zeigler DR. Integration vectors for gram-positive bacteria. Bacillus Genetic Stock Center, Catalog Strains, Seventh Edition; 2002. p. 4.

29. Stoll SM, Ginsburg DS, Calos MP. Phage TP901-1 site-specific integrase functions in human cells. J Bacteriol. 2002;184:3657.

30. Brøndsted L, Østergaard S, Pedersen M, Hammer K, Vogensen FK. Analysis of the complete DNA sequence of the temperate bacteriophage TP901-1 evolution, structure, and genome organization of lactococcal bacteriophages. Virology. 2001;283:93-109.

31. Petersen KV, Martinussen J, Jensen PR, Solem C. Repetitive, marker-free, sitespecific integration as a novel tool for multiple chromosomal integration of DNA. Appl Environ Microbiol. 2013;79:3563-9.

32. Brøndsted L, Hammer K. Use of the integration elements encoded by the temperate lactococcal bacteriophage TP901-1 to obtain chromosomal single-copy transcriptional fusions in Lactococcus lactis. Appl Environ Microbiol. 1999:65:752

33. Christiansen B, Brøndsted L, Vogensen FK, Hammer K. A resolvase-like protein is required for the site-specific integration of the temperate lactococcal bacteriophage TP901-1. J Bacteriol. 1996;178:5164-73.

34. Christiansen B, Johnsen MG, Stenby E, Vogensen FK, Hammer K. Characterization of the lactococcal temperate phage TP901-1 and its sitespecific integration. J Bacteriol. 1994;176:1069-76.

35. Ng DTW, Sarkar CA. Engineering signal peptides for enhanced protein secretion from Lactococcus lactis. Appl Environ Microbiol. 2013;79:347-56.

36. Le Loir Y, Azevedo V, Oliveira SC, Freitas DA, Miyoshi A, Bermúdez-Humarán $L G$, et al. Protein secretion in Lactococcus lactis : an efficient way to increase the overall heterologous protein production. Microb Cell Fact. 2005:4:2.

37. Yang $\mathrm{H}, \mathrm{Kim} \mathrm{Y}$, Chang $\mathrm{H}$. Construction of an integration-proficient vector based on the site-specific recombination mechanism of enterococcal temperate phage $\varphi \mathrm{FCl}$ construction of an integration-proficient vector based on the site-specific recombination mechanism of Enterococcal T. J Bacteriol. 2002;184:1859.

38. Lachica RV, Genigeorgis C, Hoeprich PD. Metachromatic agar-diffusion methods for detecting staphylococcal nuclease activity. Appl Microbiol. 1971;21:585-7.

39. Breüner $A$, Brøndsted L, Hammer K. Resolvase-like recombination performed by the TP901-1 integrase. Microbiology. 2001;147(Pt 8):2051-63.

40. Mulder J, Wels M, Kuipers OP, Kleerebezem M. Unleashing natural competence in Lactococcus lactis by induction of the competence regulator ComX. Appl Environ Microbiol. 2017;83:1-13.

41. Kuipers OP, de Ruyter PGG, Kleerebezem M, de Vos WM. Quorum sensingcontrolled gene expression in lactic acid bacteria. J Biotechnol. 1998:64:1521.

42. van de Guchte M, van der Vossen JM, Kok J, Venema G. Construction of a lactococcal expression vector: expression of hen egg white lysozyme in Lactococcus lactis subsp. lactis. Appl Environ Microbiol. 1989:55:224-8.

43. Loir YLE, Nouaille S, Commissaire J, Bretigny L, Gruss A, Langella P. Signal peptide and propeptide optimization for heterologous protein secretion in Lactococcus lactis. Appl Environ Microbiol. 2001;67:4119-27.

44. Baradaran A, Sieo CC, Illias RM, Rahim RA, Yusoff K, Foo HL. Cloning and in silico characterization of two signal peptides from Pediococcus pentosaceus and their function for the secretion of heterologous protein in Lactococcus lactis. Biotechnol Lett. 2013:35:233-8.

45. Subramaniam M, Baradaran A, Rosli MI, Rosfarizan M, Khatijah Y, Raha AR. Effect of signal peptides on the secretion of $\beta$-cyclodextrin glucanotransferase in Lactococcus lactis NZ9000. J Mol Microbiol Biotechnol. 2012;22:361-72.

46. Kuipers OP, Beerthuyzen MM, de Ruyter PG, Luesink EJ, de Vos WM. Autoregulation of Nisin Biosynthesis in Lactococcus lactis by Signal Transduction. J Biol Chem. 1995;270:27299-304.

47. de Ruyter PG, Kuipers OP, Beerthuyzen MM, van Alen-Boerrigter I, de Vos WM. Functional analysis of promoters in the nisin gene cluster of Lactococcus lactis. J Bacteriol. 1996:178:3434-9.

48. NICE. Expression System for Lactococcus lactis. 2010.
49. Madsen SM, Arnau J, Vrang A, Givskov M, Israelsen H. Molecular characterization of the $\mathrm{pH}$-inducible and growth phase-dependent promoter P170 of Lactococcus lactis. Mol Microbiol. 1999;32:75-87.

50. Madsen SM, Hindré T, Le Pennec J-P, Israelsen H, Dufour A. Two acidinducible promoters from Lactococcus lactis require the cis-acting ACiD-box and the transcription regulator RcfB. Mol Microbiol. 2005:56:735-46.

51. Jørgensen CM, Vrang A, Madsen SM. Recombinant protein expression in Lactococcus lactis using the P170 expression system. FEMS Microbiol Lett. 2014:351:170-8.

52. Leenhouts K, Buist G, Kok J. Anchoring of proteins to lactic acid bacteria. Antonie Van Leeuwenhoek. 1999:76:367-76.

53. Hansson M, Samuelson P, Gunneriusson E, Ståhl S. Surface display on gram positive bacteria. Comb Chem High Throughput Screen. 2001;4:171-84.

54. Habimana O, Bellon-Fontaine M-N, Buist G, Juillard V, Le Goff C, Briandet R, et al. Positive role of cell wall anchored proteinase PrtP in adhesion of lactococci. BMC Microbiol. 2007;7:36.

55. Dagert M, Ehrlich SD. Prolonged incubation in calcium chloride improves the competence of Escherichia coli cells. Gene. 1979;6:23-8.

56. Holo H, Nes I. Transformation of Lactococcus by electroporation. Methods Mol Biol. 1989:47:195-9.

\section{Publisher's Note}

Springer Nature remains neutral with regard to jurisdictional claims in published maps and institutional affiliations.
Ready to submit your research? Choose BMC and benefit from:

- fast, convenient online submission

- thorough peer review by experienced researchers in your field

- rapid publication on acceptance

- support for research data, including large and complex data types

- gold Open Access which fosters wider collaboration and increased citations

- maximum visibility for your research: over $100 \mathrm{M}$ website views per year

At $\mathrm{BMC}$, research is always in progress.

Learn more biomedcentral.com/submissions 